\title{
5 New Transnational Pan-Africanism and Its Nationalist Limitations
}

\section{Introduction}

Adequate knowledge of the past remains critical for understanding the present era and the future in order to appreciate the evolution of events. Pan-Africanism is highly relevant to the discourse on nationalism and internationalism considering the involvement of different groups of people across nation state borders. This is because the issues generated by Pan-African initiatives offer more insight into how continental developments became globalized and entrenched attributes of the black people wherever they find themselves. Every issue concerning PanAfricanism offers an opportunity for a reflection on the past and how to forge a new identity for Africans in this 21st century that has rather become highly contested across the world. Having a classed world in terms of culture, race, technology, and development indicates that nationalism at the continental level achievable through transnational Pan-Africanism is inevitable and must be prioritized for the expected outcome to be realized.

The transnational nature of nationalism in this context shows how PanAfricanism is a collaborative endeavor that brings people from African ancestry together. Pan-Africanism has given birth to clichés like the African dream, African personality, neo-Africanism, black consciousness, black pride, dignity of blacks, and blacks in the diaspora. Africanization as a development now transcends the political independence of the states in Africa to the extent that the much-championed unity is dependent on the ability of people to come under one umbrella of ideas to forge an ethnic African identity.

Transnational Pan-Africanism has become a new pathway to the realization of an African dream of unity, cooperation, and development in this globalized world where identity now matters and remains significant to the actualization of many African-centered interests. ${ }^{1}$ Pan-Africanism and the ideas that promote Africanness have given scholars a platform to study and engage in the discussion of issues or affairs concerning the continent.

Historically, the term Pan-Africanism was first used by Henry Sylvester Williams (1867-1911), who was a barrister from Trinidad, then the West Indies, and

1 Ernest T. Aniche, "From Pan-Africanism to African Regionalism: A Chronicle," African Studies 79, no. 1 (2020): 3.

Ә Open Access. (C2021 James Okolie-Osemene, published by De Gruyter. (c) BY-NC-ND This work is licensed under the Creative Commons Attribution-NonCommercial-NoDerivatives 4.0 International License. 
while in England, he received complaints from African chiefs and other dignitaries, and this culminated in the first Pan-African conference in 1900 held in London. ${ }^{2}$ A conference that recorded the participation of over thirty delegates can be described as impactful as it charted a new course for African solidarity, with commendations from London's Lord Bishop and Queen Victoria. Pan-Africanism was categorized into four periods by historian and political scientist Vernon McKay, namely, 1900-1945 and 1945-1957, the period when Kwame Nkrumah (1909-1972) became Ghana's president (1957), and was characterized by disunity, as well as the years since $1970 .^{3}$

The All-African Peoples' Conference (AAPC) is traceable to Pan-Africanist ideas, which informed the movement that metamorphosed into an intellectual gathering of all people of African descent whose effort remains sustaining the discussion and exchange of ideas at the individual, subgroup, and group levels.

A corpus of literature exists on Pan-Africanism. These works examine PanAfricanist citizenship, political Pan-Africanism, black solidarity, Nkrumah's vision of Pan-Africanism, Pan-Africanist protagonists, ${ }^{4}$ Pan-African youth, Ubuntu as a Pan-African revolutionary ideology, the idea and movement of Pan-Africanism, ${ }^{5}$ the unfinished project of Pan-Africanism, and decolonization. ${ }^{6}$ Despite the potentials of using the platform of new Pan-Africanism to promote the African dream, most scholarly works have not focused on the transnational nature of the AAPC, especially as it concerns the future of nationalism, which is expected to impact the political reality in Africa.

This contribution examines the new transnational Pan-Africanism and its nationalist limitations with the aim of establishing the functionality of the AllAfrican Peoples' Conference in reinforcing new Pan-Africanism, thereby reviving black consciousness. The study explores how the new Pan-African nationalism can address Africa's leadership question, using constructivist theory as its framework of analysis. This work is divided into seven sections, namely, introduction, Pan-African ideas: meaning and evolution, theoretical framework, the contemporary significance of Pan-African congress resolutions in Paris, nationalism-oriented

2 William J. Middleton, "Pan-Africanism: A Historical Analysis and Critique," The Black Scholar: Journal of Black Studies and Research 1, no. 3-4 (1970): 58.

3 Middleton, "Pan-Africanism" 58.

4 Vanessa Van den Boogaard, "Modern Post-Colonial Approaches to Citizenship: Kwame Nkrumah's Political thought on Pan-Africanism," Citizenship Studies 21, no. 1 (2017): 5-8.

5 Albert Kasanda, "Exploring Pan-Africanism's theories: From race-based solidarity to political unity and beyond," Journal of African Cultural Studies 28, no. 2 (2016): 179-195.

6 Kurt B. Young, "Towards a holistic review of Pan-Africanism: Linking the idea and the movement," Nationalism and Ethnic Politics 16, no. 2 (2010): 141-163. 
aspects of the Pan-African idea, nationalist limitations of the new Pan-Africanism, and conclusion and recommendations. In terms of methodology, the study is qualitative. It combines both primary and secondary sources of data, including participant observation of the 2018 AAPC in Ghana, where the author interacted with participants and some of those who were part of the 1958 event in Accra, Ghana. It also combines a historical analytical approach with a theme mapping.

\section{Pan-African Ideas: Meaning and Evolution}

What Pan-Africanism means has gone a long way toward shaping the pattern and evolution of the idea and movement, which greatly determined the efforts of individuals and groups. Pan-Africanism encourages the running of African institutions for the interest and benefit of Africa as championed by Kwame Nkrumah, who was the first President of Ghana and an advocate of African transnationalism and integration. ${ }^{7}$ The significance of Pan-Africanism has been demonstrated by various political parties across the continent which endeavor to have African-related names. For instance, two political parties in Togo have “Africa” in their party names: the Parti Démocratique Panafricain (PDP) and the Convergence Patriotique Panafricaine (CPP). This is an indication that Africa or Pan-Africa has become an identity for some institutions within the continent.

Nigerian historian Godfrey Uzoigwe identified "the chequered history of the Pan-African Movement as well as the epistemological problems associated with the Pan-African ideology."8 From the activities and publications of the PanAfricanists, Pan-Africanism has been classified into an idea and a movement, both portraying two phases of development. ${ }^{9}$ Similarly, in terms of conceptual significance, Pan-Africanism refers to "a political and cultural phenomenon which in the early stages, regarded Africa, Africans and Persons of African stock as a unit, with the aim of generating the African solidarity among the people."10 Such solidarity is premised on the need to demonstrate the richness of African socio-economic and political values. Africa has remained a center

7 Boogaard, "Modern Post-Colonial Approaches to Citizenship," 6.

8 Godfrey N. Uzoigwe, "A Matter of Identity: Africa and Its Diaspora in America Since 1900, Continuity and Change," African and Asian Studies 7 (2008): 260.

9 Peter Olisanwuche Esedebe, “The Emergence of Pan African Ideas," in Themes in African Social and Political Thought, ed. Onigu Otite (Enugu: Fourth Dimension Publishing, 1978), 75.

10 Esedebe, "The Emergence of Pan African Ideas," 75. 
of attention since the pre-colonial era when the slave trade and the scramble for Africa troubled the continent. To show the strategic nature of Africa in world politics, great power politics also revolve around the continent as a majority of great powers in history had to focus their foreign policy objectives toward Africa.

Pan-Africanism is generally regarded as an intervention of African peoples over what they view as a Eurocentric conspiracy targeting blacks and aimed at sustaining the dependence of Africa on the developed world and the continuous exploitation of its people by those in the Western world. ${ }^{11}$ So, this intervention is centered on advocacy for equity in the interest of Africa. According to Ndlovu-Gatsheni, Pan-Africanism, which recognizes the contemporary international system as a racially hierarchized, partial, imperial, colonial, and capitalist global social order, is a movement that emerged as a result of black racial consciousness and sought to challenge the domination of Africa by a Eurocentric-centered world system. The latter's existence gives little opportunity to the less privileged race to actualize their potentials through what is generally perceived as the oppression, abuse, and exploitation of black identity by white racial groups who desire continuous economic, technological, etc. dependences on the West. $^{12}$

Bunting states that

Pan Africanism is an ideology and an objective informed by the culture values, beliefs and customs of African peoples and their experiences that have developed over the past six centuries of the modern era. The experiences of African peoples and states have, over this epoch, been as both resisters to, and victims of, the systems, policies and practices of dehumanization and commodification of their bodies, lands and culture in capitalist relations within an imperialist framework. ${ }^{13}$

Pan-Africanism is traceable to the efforts of the people of Africa who crossed the Atlantic to the Americas and Europe and who later returned to the African

11 Mark Malisa and Phillippa Nhengeze, "Pan-Africanism: A Quest for Liberation and the Pursuit of a United Africa,” Genealogy 2, no. 28 (2018): 11. Also, Walter Rodney identified an unequal relationship between underdeveloped countries and the developed world as one of the sources of their exploitation for the benefit of the capitalist world. Walter Rodney, How Europe Underdeveloped Africa (London: Bogle-L'Ouverture Publications, 1972), 34.

12 Sabelo J. Ndlovu-Gatsheni, "Pan-Africanism and the international system." in Handbook of Africa's International Relations, ed. Tim Murithi (London: Routledge, 2013), 21-22.

13 Ikaweba Bunting, "Towards a Pan African Political Culture: Critical Pedagogy, Reparative Justice and the End of Global White Supremacy," Contemporary Journal of African Studies 6, no. 1 (2019): 146. 
continent, where the movement has continued to evolve over time. ${ }^{14}$ It is an old movement, like old wine in new bottles, but its novelty continues to change. Beyond the color of the skin or racial differences, Pan-Africanism has been viewed as a valuable instrument of human dignity as the world aims to promote global justice and human rights protection for all. ${ }^{15}$ The hospitable and tolerant/accommodating norms of traditional African society therefore could be translatable to the sustenance of values that promote nationalistic feelings amongst the peoples of the continent.

Edward Wilmot Blyden (1832-1912) was seen as the originator of Pan-African ideas. Blyden was born of "pure Negro descent from the Eboe (Igbo) tribe, in August 1832 on the Danish West Indian Island of West Thomas. His grandfather came to the West Indies from Igboland." "As the father of Pan-Africanism, Blyden's studies made him more of an African and, more passionately, the upholder of an African soul, an African culture, an Africa of clearly demarcated and peculiar racial needs. ${ }^{17}$ He excelled in his endeavor and succeeded in passing the baton to the younger generation of Africans who took up the task from where he stopped. Just like Blyden, W. E. B. DuBois (1868-1963) also deserves commendation for his relentless efforts in developing leadership in the struggle against imperialism which affected black people and their quest to eradicate exploitation and domination by the imperial powers in Europe, and he was able to devise new tactics against imperialism through his agitations for a common front of all African nations beyond the 1919 Pan-African Congress in Paris. ${ }^{18}$ Various circumstances have been responsible for Africa's struggles to take control of her own destiny since the beginning of the last century, which also inspired the first Pan-African Congress that was held in London in 1900. ${ }^{19}$ This was highly supported and motivated by Henry Sylvester Williams. $^{20}$ All these aspects point to one critical issue, i.e. that Pan-Africanism

14 Timothy A. Otunla, "Pan-Africanism with the African Union: Policy Options for Nigeria," in New Horizons for Nigeria in World Affairs, ed. Joy U. Ogwu (Lagos: The Nigerian Institute of International Affairs, 2005), 314-315.

15 Kasanda, “Exploring Pan-Africanism's theories,” 179.

16 Esedebe, "The Emergence of Pan African Ideas," 81-83.

17 Harry N. K. Odamtten, Edward W. Blyden's Intellectual Transformations: Afropublicanism, Pan-Africanism, Islam, and the Indigenous West African Church (Michigan: Michigan State University Press, 2019).

18 Franklin Alexander, “A critique of neo-Pan-Africanism," The Black Scholar: Journal of Black Studies and Research 4, no. 10 (1973): 10-13.

19 Benedict Orhioghene Akpomuvie, "Pan-Africanism and the Challenges of Development in the 21st Century,” Africana 4, no. 2 (2010): 193.

20 Abubakar Momoh, "Does Pan-Africanism Have a Future in Africa? In Search of the Ideational Basis of Afro-Pessimism,” African Journal of Political Science 8, no. 1 (2003): 43. 
remains an African project which unites people desirous of regaining the destiny of the continent with a view to transforming the feelings of dependence and a stranded situation. Despite the significance of color as a symbol of identity in Pan-Africanism, the idea is that this has remained a remarkable building block and source of group definition and mobilization, one that has the capacity to enable Africans to realize their transnational goals hinged on what is described as "anti-colonial nationalism," ${ }^{21}$ which is regarded as a more peopleoriented and progressive nationalism. ${ }^{22}$ In other words, such nationalism must be anti-imperial, in contrast to many post-nation-state nationalisms that are imperial, as they are directed toward the control of exterior territory.

It is only easy to form a movement and embark on advocacy projects when an idea exists. The people who championed Pan-African ideas were able to ignore whatever differences they had to pursue a common goal of liberation. Various experiences inspired the ideas that led to Pan-Africanism. Such thoughts that later manifested were further strengthened by the perennial neglect of African affairs to the detriment of Africans in other parts of the world. The foregoing made some Africans adopt the Moorish proverb "He who fears something gives it power over him"23 when confronting their seemingly ugly past. In essence, they chose to shape their destinies for the better. Black people were generally seen as Negroes in most parts of the world. However, the back-to-Africa idea also appealed to African descendants in the West Indies where discrimination and marginalization against Africans manifested in a situation where black people were considered as slaves and people of low status, usually proven by a kind of evidence, as contained in the Antiguan Legislation of $1783 .{ }^{24}$

According to James Africanus Beale Horton (1835-1883), Africa produced many of the famous theologians of the early Christian Church, notably Origen, Tertullian, Augustine, Clement of Alexandria, and Cyril, a reasoned re-assessment of the continent that exposed the ignorance of racists. ${ }^{25}$ Pan-Africanists believed in the idea that no condition was permanent, as Horton argued, to develop hope for a grand African future. ${ }^{26}$ Through the ideas developed, Africans sought to work on their psyche to eradicate all forms of inferiority in the international community.

21 Brandon Kendhammer, "DuBois the pan-Africanist and the development of African nationalism,” Ethnic and Racial Studies 30, no. 1 (2007): 54.

22 Ehimika Adebayo Ifidon, "Did Pan-Africanism beget Nationalism? Race and Territory in the Discourse on Pan-Africanism,” Lagos Historical Review 8 (2008): 113-131.

23 Lindsay McKenna, Commando (Don Mills, Ont.: Harlequin Enterprises, 2013), 106.

24 Esedebe, “The Emergence of Pan African Ideas," 81.

25 Ibid.

26 Ibid. 
Pan-Africanism offered a great opportunity to Africans to enlighten the world that their continent is good and a place of positive realities. Pan-Africanism can be described as an African initiative of mobilization for change to enhance the global understanding of the continent. The development of Pan-African ideas and the movement thereafter led to various congresses in later years.

The significance of these observations is that Pan-Africanism promotes transnational relations in Africa for the entire continent to have a platform for the discussion and management of their affairs in unity.

\section{Theoretical Framework}

Several theories have been used to explain issues arising from relationships among groups. Apart from social identity theory, which was developed by Henri Tajfel (1919-1982) in the 1970s and explains how individuals develop their selfconception(s) on the basis of their attachment to a significant group with implications for self-awareness, realistic group theory, formulated by Muzafer Sherif (1906-1988), identifies how the hostility between two groups results from real or perceived conflicting goals. ${ }^{27}$ Here, constructivist theory is adopted as the framework for analyzing the new transnational Pan-Africanism in contrast to local nationalisms within states.

The essence of this theoretical consideration is to explore the linkages between nationalism and the new transnational Pan-Africanism, which can be described as dichotomous in Africa, considering the involvement of different groups. There are various groups across the world, and this explains why we have cultural differences within groups and sub-groups with diverse levels of intergroup relations. The characteristics of ethnicity vary with different cultural distinctiveness. ${ }^{28}$ The social construction of the identities, interests, and behaviors of people explains the mediative position of constructivists. ${ }^{29}$

According to Andreas Wimmer, Thomas Fredrik Weybye Barth (1928-2016), a renowned Norwegian social anthropologist, pioneered what later became known as "constructivism," which focuses on the claim that ethnicity is the product of a

27 Joaquim Pires Valentim, "Sherif's Theoretical Concepts and Intergroup Relations Studies: Notes for a Positive Interdependence,” Psychologica 52, no. II (2010): 585-598.

28 Andreas Wimmer, "The Making and Unmaking of Ethnic Boundaries: A Multilevel Process Theory," American Journal of Sociology, 113, no. 4 (2008): 97-99.

29 Emanuel Alder, "Seizing the Middle Ground: Constructivism in World Politics," European Journal of International Relations 3, no. 3 (1997): 321-324. 
social process rather than a cultural given, made and remade rather than taken for granted, chosen depending on circumstances rather than ascribed through birth. ${ }^{30}$ The works of Fredrik Barth reveal the impact of different peoples with distinct cultures coming together to accommodate themselves in order to develop interestbased understandings, with the stability of ethnic characteristics impacting on inter-ethnic contact, thereby creating the opportunity for group complementarity to determine the positive bond that connects several ethnic groups in an encompassing social system. ${ }^{31}$ In other words, inter-ethnic relations sustain interaction for the achievement of various objectives. Also, Emanuel Alder posits that constructivists "believe that 'ideas' have structural characteristics. Ideas - understood more generally as collective knowledge, institutionalized in practices - are the medium and propellant of social action; they define the limits of what is cognitively possible and impossible for individuals. ${ }^{32}$ In the same vein, constructivism is the view that the manner in which the material world shapes and is shaped by human action and interaction depends on dynamic normative and epistemic interpretations of the material world..$^{33}$ As seen from the foregoing, it can be adduced that the circumstances surrounding the African predicaments necessitated the coming together of concerned people to discuss the issues and identify the ways forward to forge a new identity for black man. With Pan-Africanism, Africa is seen as the 'motherland' and home where people of black origin can identify, irrespective of their cultures within the African family they share, in the form of constructed unity. $^{34}$

Constructivism emphasizes how most enduring institutions are based on collective understandings, while constructivists believe that the human capacity for reflection or learning has its greatest impact on the manner in which individuals and social actors attach meaning to the material world and cognitively frame the world they know, experience, and understand. Thus, collective understandings provide people with reasons why things are as they are and indications as to how they should use their material abilities and power..$^{35}$ The nationalist limitations of new Pan-Africanism are obviously situated in this constructivist perspective.

30 Wimmer, "The Making and Unmaking of Ethnic Boundaries," 99-101.

31 Fredrik Barth, "Introduction," in Ethnic Groups and Boundaries: The Social Organization of Culture and Difference, ed. Fredrik Barth (Boston: Little Brown and Company, 1969), 16-22.

32 Alder, "Seizing the Middle Ground," 325.

33 Wimmer, "The Making and Unmaking of Ethnic Boundaries," 100-101.

34 Katharina Schramm, "Pan-Africanism as a Resource: The W. E. B. DuBois Memorial Centre for Pan-African Culture in Ghana,” African Identities 2, no. 2 (2004): 157.

35 Alder, "Seizing the Middle Ground," 322. 


\section{The Contemporary Significance of Pan-African Congress Resolutions in Paris}

In 1919 the Pan-African Congress was held in Paris. Since that time, i.e. in the last 100 years, the position of Africa has remained a source of concern to all who care to think about group survival because it is not disputable that Africans have equal rights like those in other parts of the world. The following resolutions were made during the 1919 Pan African-Congress:

- That the Allied and Associated Powers establish a code of law for the international protection of the natives of Africa, similar to the proposed international code for labor;

- That the League of Nations establish a permanent Bureau charged with the special duty of overseeing the application of these laws to the political, social, and economic welfare of the natives, meaning the people of Africa are in a better position to address their needs;

- The Negroes of the world demand that hereafter the natives of Africa and the peoples of African descent be governed according to the following principles:

(a) The land: the land and its natural resources shall be held in trust for natives and at all times they shall have effective ownership of as much as they can profitably develop;

(b) Capital: the investment of capital and granting of concessions shall be so regulated as to prevent the exploitation of the natives and the exhaustion of the natural wealth of the country. Concessions shall always be limited in time and subject to state control. The growing social needs of the natives must be regarded and the profits taxed for the social and material benefit of the natives;

(c) Labor, slavery, and corporal punishment shall be abolished and forced labor except in punishment of crime, and the general conditions of labor shall be prescribed and regulated by the state;

(d) Education: it shall be the right of every native child to learn to read and write his own language, and the language of the trustee nation, at public expense and to be given technical instruction in some branch of industry;

(e) The state: natives of Africa must have the right to participate in the government as fast as their development permits, in conformity with the principle that the government exists for the natives and not the 
natives for the government. They shall at once be allowed to participate in local and tribal government. ${ }^{36}$

This was aimed at promoting the Africans' rights in having an active participation in government. ${ }^{37}$ It is believed that the best way to guarantee the interest of people is to offer them the opportunity of participatory development, which gives them a sense of belonging. It is instructive that, at the time of the PanAfrican Congress in Paris, most of the black nations were still under the bout of colonialism as they had little or no influence on colonial policies. During this period, they were yet to have the autonomy to have a formidable transnational impact, considering how the demands centered on socio-economic and political rights that gave little priority to decolonization. This notwithstanding, the congress further cemented the foundations for future transnational activities that sought to forge a united Africa.

\section{Nationalism-Oriented Aspects of the Pan-African Idea}

Prior to the AAPC, we could see that Pan-African ideas began from identifying the essence of understanding and knowing that the international community has an obligation to listen to the people. The following are nationalism-oriented aspects of Pan-Africanism:

1. The origin is traceable to race consciousness that inspired advocacy programs against domination, discrimination, and anti-African policies.

2. This led to the formation and operation of social movements and sharing of some operational features of social groups.

3. Pan-Africanism offered an opportunity for the people to project the positive past history of Africa.

4. With a transnational outlook, both the movement and its ideology were anchored on popular slogans like "Africa for Africans" and "African personality" (this is based on the goal of projecting Africans as global citizens).

36 Colin Legum, Pan-Africanism: A Short Political Guide (New York: Frederick A. Praeger, 1965), 353.

37 Momoh, "Does Pan-Africanism Have a Future in Africa," 45. 
Pan-Africanists adopted the modus operandi of persuading the international community to grant Africa her rights. For instance, the 5th Pan-African Conference was held in Manchester from 15 to 21 October 1945, and this one contributed to the liberation of African countries. They advocated for the freedom of the press in the colonies, among other things. In attendance were Jomo Kenyata (1891-1978), Kwame Nkrumah (1909-1972), Hastings Kamuzu Banda (1898-1997), the South African novelist Peter Henry Abrahams (1919-2017), Jaja Nwachukwu (1918-1996), and Obafemi Awolowo (1909-1987). At the end, they resolved that "We shall complain, appeal and arraign. We will make the world listen to the facts of our condition. We will fight in every way we can for freedom, democracy and social betterment." 38 This period marked the first time that the necessity for wellorganized movements as a primary condition for the success of the national liberation struggle in Africa was discussed. ${ }^{39}$ The true color of African unity was made manifest through the series of meetings organized in different locations in the name of Africa and for the continent. Apart from the involvement of students in universities and various African educational institutions in promoting black consciousness, ${ }^{40}$ the clergy were not left out as the Pan-African conference of clergymen was held in Kampala in $1963 .{ }^{41}$ This was the spiritual dimension of the struggle considering the involvement of religious leaders. It developed the perception of African unity, which was backed by the spirit of brotherhood. By implication, it became an active movement that led to decolonization.

The contributions of Pan-Africanists to the actualization of the African dream of liberation and self-determination are noteworthy, from George Padmore, who saw communism as dogmatic and dividing, to W. E. B. DuBois, who had an interest in a Pan-African type of democracy that would strengthen the Pan-African movement. ${ }^{42}$ Marcus Garvey's approach to the emancipation of Africans also inspired Kwame Nkrumah. They all motivated themselves in one way or another.

The notable Pan-Africanists like W. E. B. DuBois, George Padmore, Marcus Garvey, Kwame Nkrumah, Jomo Kenyatta, Nnamdi Azikiwe, and Leopold Senghor shared a vision of Africa characterized by freedom and self-determination to position the people to contribute to human culture, science, and civilization

38 Naij, A History of Nigeria, directed by Jide Olanrewaju (2008). Accessed March 5, 2021. https://www.youtube.com/watch?v=KgrVHrTvxC8.

39 Nkrumah, quoted in Olanrewaju, Naij, A History of Nigeria.

40 Malisa and Nhengeze, "Pan-Africanism," 9.

41 Ivan Potekhin, "Pan-Africanism and the Struggle of the Two Ideologies," South Africa History Online (October 1964): 41.

42 Momoh, "Does Pan-Africanism Have a Future in Africa," 45. 
as a transnational union of states. ${ }^{43}$ In many ways, Pan-Africanism gave rise to nationalist thought and the emergence of African nationalist movements. Observations have shown that the activities of Pan-Africans also contributed to the socio-economic and political emancipation of the people. By implication, the level of enlightenment has improved to the extent that, beyond education, the people now know their rights and the need to govern themselves without unnecessary external interference.

From various developments and scholarly publications, the new transnational Pan-Africanism is synonymous with the Republic of Ghana, considering how its leaders and institutions hosted people from various parts of the world. Besides, both scholars and the leadership class have identified the transnational efforts of Ghana as a symbolic territory in mobilizing all African states after being the first on the continent to gain independence in $1957 .{ }^{44}$ Likewise, the establishment of the W. E. B. DuBois Memorial Centre for Pan-African Culture in 1985 is proof of Ghana's commitment to the Pan-African cause ${ }^{45}$ by honoring DuBois, who vehemently opposed the colonial occupation and exploitation during his lifetime. ${ }^{46}$ Significantly, the Ghana Studies Association describes the country as at the center of the world both geographically, where the Greenwich Meridian meets the Equator, and also conceptually, where themes that study critical studies on Africa such as Pan-Africanism, the transatlantic slave trade, colonialism, statebuilding, and development are investigated. From the foregoing, it is not surprising why Ghana hosted the AAPC in 1958 and 2018. ${ }^{47}$ African experiences since the preindependence era have revolved around the transatlantic slave trade, colonialism, imperialism, state-building, and the need to curb underdevelopment. In fact, after the independence of Ghana, the country became known as "the model of freedom and an inspiration to other African nations." ${ }^{48}$ With the establishment of the Institute of African Studies at the University of Ghana in 1963, Ghana became the center of studies and knowledge development on African history, culture,

43 Akpomuvie, "Pan-Africanism," 194.

44 Van den Boogaard, "Modern post-colonial approaches to citizenship," 5.

45 Schramm, "Pan-Africanism as a Resource," 157.

46 Kendhammer, "DuBois the Pan-Africanist,"52.

47 During the 2018 AAPC, participants discussed how the 1958 attendees resolved to use the platform created by Ghana to assist African states to gain their much-desired freedom and selfdetermination. As Ghana hosted the event, it was another opportunity for the 2018 participants to review achievements, obstacles, and the way forward.

48 Toyin Falola and Chukwuemeka Agbo, "The Prospects and Challenges of Pan-Africanism," Oxford Research Encyclopedia: Politics, published online July 29, 2019, https://doi.org/10.1093/ acrefore/9780190228637.013.718. 
arts, and languages. ${ }^{49}$ Earlier, Ghana had hosted Africans living in the diaspora as an icon of Pan-Africanism in theory and practice, to the extent that Eddie Mack Ross sojourned to Ghana on a Pan-African Congress tour where he contracted malaria and died after returning to the United States. This led to his daughter, Shirikiana Aina, producing a film called Footprints of Panafricanism, which highlights the diaspora-Ghana connection that demonstrates Kwame Nkrumah's passion and love for blacks. ${ }^{50}$ In the early years of independence, Ghana became a safe and peace-oriented home for all Africans desirous of freedom and a safe haven, even when most new states in Africa were crisis-ridden as a result of protracted intra-state conflicts. With Ghana, Africa already had a continent-focused platform for Pan-African nationalism and solidarity for the muchdesired transformation through the revolutionary initiative of the AAPC's new Pan-Africanism.

The advent of the AAPC consequently marked a watershed in the history of Pan-Africanism because ordinary people became partners in problem-solving with the leaders of the day. Prior to the AAPC, the Conference of Independent African States was held in Accra in 1958 and hosted eight independent African states (as well as South Africa), comprising five from the Arabic North and three from Sub-Saharan Africa, with the articulation of the idea that Africans needed to project a distinct identity onto the world stage, which Nkrumah termed the "African Personality." The AAPC, which was held in Accra, witnessed the participation of leaders and groups that were still fighting to liberate their territories from European and white settler rule in Africa. It included figures such as Patrice Lumumba (1925-1961) and Holden Roberto (1923-2007). In April 1960, Accra also hosted the Positive Action Conference, which was attended by African nationalists and Pan-Africanists, as well as representatives of leftist organizations largely from the West. ${ }^{51}$ Their efforts were focused on advancing the socialist vision in the form of scientific socialism, driven by a united front against imperialism and aimed at embracing a non-capitalist way of development ${ }^{52}$ with the hope of actualizing the desired socio-economic justice and black empowerment. ${ }^{53}$ As a

49 Ghana Studies Association, 2019.

50 Nubia Kai, “Footprints of Pan-Africanism," Journal of African Literature Association 12, no. 3 (2018): 362-363.

51 Harcourt Fuller, Building the Ghanaian Nation State: Kwame Nkrumah's Symbolic Nationalism (New York: Palgrave Macmillan, 2014), 137.

52 Potekhin, "Pan-Africanism and the Struggle of the Two Ideologies."

53 Said Adejumobi, "Popular Participation and Africa's Development Agenda: Projecting a Citizen-Based United States of Africa," Politikon: South African Journal of Political Studies 36, no. 3 (2009): 405. 
result, both Pan-Africanism and socialism were linked together, with the latter having the capacity to facilitate "radical social changes" manifested in economic liberation, as identified by Nkrumah, ${ }^{54}$ to produce a socialist Pan-African economy, thereby making Pan-Africanism an ideology of development. ${ }^{55}$ These meetings, including the first AAPC and the Positive Action Conference, which laid the foundations for the 2018 AAPC, showed the significance of transnational Pan-Africanism in actualizing the objectives of black people in a highly competitive world characterized by global stratification.

Table 1: Levels of Exchanges.

\begin{tabular}{ll}
\hline Level & Category \\
\hline Individual & Paper presentations \\
\hline Sub-group & Panel discussions/contributions by the audience \\
\hline Group & $\begin{array}{l}\text { Gatherings of all congress participants where all panelists and audience } \\
\text { members hold a discussion to draft a communiqué }\end{array}$ \\
\hline Publicity & Reaching out to policymakers and the intellectual community \\
\hline
\end{tabular}

Table 1 shows the levels of exchange from the individual to publicity levels which facilitate the actualization of the new Pan-Africanism through the collaboration of all stakeholders. Transnationalism within this context breaks the colonial boundaries inherited by the independent states of Africa with the aim of forging a new identity through the new Pan-Africanism initiated and sustained by scholars. Such an effort has been a driver of the continental-centered loyalty of the blacks.

\section{Nationalist Limitations of the New Pan-Africanism}

Remarkably, the AAPC is a platform for Pan-Africanism because it began as a meeting of African peoples and spread through the conference held at different intervals with the aim of advancing Africans' future in a highly stratified world of white superiority that has scared black people since the pre-colonial era.

54 Micah S. Tsomondo, "From Pan-Africanism to Socialism: The Modernization of an African Liberation Ideology,” Issue: A Journal of Opinion 5, no. 4 (1975): 39.

55 Opeyemi Ola, "Pan-Africanism: An Ideology of Development," Présence Africaine 4, no. 112 (1979): 68-77. 
The 1958 conference was initiated by the only eight independent African states, namely Ethiopia, Egypt, Ghana, Liberia, Libya, Morocco, Tunisia, and Sudan, and the total liberation of Africa was at the core of their agenda. They resolved to denounce the division of African communities to the extent that brothers became alienated from their relatives and neighbors.

Although this goal was achieved, the liberation of African states through independence has not produced much of an impact in the lives of black people, especially in ending the exploitative and unequal relationship between African states and the developed world where foreign aid flows to Africa with dependency and resource implications. Meanwhile, during the early years of independence, the views of Walter Rodney characterized the relationship between Africa and the great powers. According to Rodney, the control of African societies by the capitalist powers increased the structuring of dependence on developed countries, as well as the exploitation and exportation of surplus natural resources, thereby making the imperialist forces agents of underdevelopment, without any tangible industrialization in the form of factories or a technological approach to food production like mechanized agriculture. ${ }^{56}$ The foregoing has been worsened by the poor leadership that makes Africa a mockery of the world, considering the gap between the leaders of the first eight independent African states in 1958 and those in power today.

Although the significance of the new Pan-Africanism initiated in 2018 cannot be downplayed, the fact that the University of Ghana in East Legon played a strategic role in the convening of the AAPC when then-president Kwame Nkrumah organized the program also needs to be seen by other African countries as an acceptance of responsibility rather than as a matter of superiority. This is because Nkrumah refused to have any satisfaction until all African states were liberated in view of his perception and conviction that Africa was not an extension of other continents, and this made him establish contact with other African leaders and their peoples. ${ }^{57}$ Also, the landmark 2018 event advanced the ideals of African culture and co-existence, as it created a platform for scholars and civil society to identify and discuss the implications of oppressive tendencies in Africa and outside Africa where blacks suffer different kinds of humiliation because of their roots. It was an opportunity for Africans to reassert their position in the world to discourage the perception of a white-dominated world where every global policy is determined by the West to the detriment of Africa. This

56 Rodney, How Europe Underdeveloped Africa, 24-34.

57 The discussions during the 2018 AAPC centered on ways of building on the foundation already established by the founding fathers of Pan-Africanism for the actualization of the set objectives. 
has the potential to reposition African states in the ever-changing economic world order. The equity promotion themes discussed at the conference will certainly influence the leadership styles of leaders in Africa to run a people-centered governance system rather than excluding minorities from the policy-making and implementation processes.

Although several regimes have been accused of being oppressive and therefore been deposed through external interventions, such external involvement in African affairs must be stopped, but African leaders are expected to learn from the assassinations of Muammar Gaddafi, Thomas Sankara, Amilcar Cabral, and others to prioritize African solutions to African problems.

The 2018 event showed that political will and a combination of ideas can change Africa for good. The program also offered scholars the opportunity to display and share their experiences and publish works on African studies.

Pan-Africanism has become expedient to enable African states and their leaders to overcome the re-colonization trap occasioned by the endless dependency syndrome that is sustained by modernization views and the perceptions of self-centered leaders who think the self-sufficiency of African states is a white elephant project. Overcoming this elite threat demands concerted efforts by all and sundry to confront this limitation through the instrumentality of African solutions to African problems. Such an intervention must be done without any external support to give it the needed socio-economic attributes. One of the lessons from the new Pan-Africanism is that the majority of Africans are desirous of a change that would transform the continent. Through this new Pan-Africanism, scholars and practitioners have made their position known to the ruling class in Africa that what they focus on must not begin and end with winning the next election and initiating oppressive policies to consolidate their grip on power, but rather that the welfare of the people they govern should be prioritized.

Table 2 shows the differences and similarities between the 1958 and 2018 AAPCs. As the leaders in 1958 identified the relevance of the Pan-African conference despite the varying nationality origins, those ruling Africa today do not have excuses. While the Pan-Africanists strategized to counter colonial administrators in the past, the current movement cooperates to project the image and position of Africans to rise above neo-colonialism and recolonization agenda. With the understanding of African leaders that the rule of law and not the rule of men is more development-oriented in every political system that wishes to protect human dignity and create socio-political order, the continent's leadership crisis will become a thing of the past, bearing in mind that the home (Africa) must be stable first before external threats can be overcome by all. Pan-African nationalism can only be result-oriented when leaders use the rule of law to create a platform for 
Table 2: Comparison of AAPC 1958 and AAPC 2018.

\begin{tabular}{lll}
\hline AAPC 1958 & AAPC 2018 \\
\hline 1 & $\begin{array}{l}\text { Majority were politicians and people from } \\
\text { grassroots }\end{array}$ & $\begin{array}{l}\text { Most were scholars and members of civil } \\
\text { society }\end{array}$ \\
\hline 2 & $\begin{array}{l}\text { Organized by Kwame Nkrumah and held at } \\
\text { the Institute of African Studies, University of } \\
\text { Ghana }\end{array}$ & $\begin{array}{l}\text { Participants hosted by the Institute of } \\
\text { African Studies, University of Ghana }\end{array}$ \\
\hline 3 & $\begin{array}{l}\text { Outcome was that leaders resolved to end } \\
\text { the oppression and colonization of Africans }\end{array}$ & $\begin{array}{l}\text { Resolved to address bad leadership, } \\
\text { dependency, and inequality in } \\
\text { international politics }\end{array}$ \\
\hline 4 & Operated like a social movement & $\begin{array}{l}\text { Mobilized more scholars than ordinary } \\
\text { people }\end{array}$ \\
\hline 5 & $\begin{array}{l}\text { Leaders identified the problem of colonialism } \\
\text { and the need for liberation }\end{array}$ & $\begin{array}{l}\text { Identified leaders as part of the problem } \\
\text { and that they must be part of the solution }\end{array}$ \\
\hline 6 & Identified the need to end neo-colonialism & $\begin{array}{l}\text { Identified intractable white superiority as } \\
\text { a threat to Africa }\end{array}$ \\
\hline 7 & $\begin{array}{l}\text { Showcased Ghana as the center of African } \\
\text { affairs }\end{array}$ & $\begin{array}{l}\text { Showed that Ghana is the center of Pan- } \\
\text { Africanism }\end{array}$ \\
\hline 8 & $\begin{array}{l}\text { Demanded the creation of a common front by } \\
\text { all Africans against imperialism }\end{array}$ & $\begin{array}{l}\text { Sent a message to the leadership class } \\
\text { and the developed countries }\end{array}$ \\
\hline 9 & $\begin{array}{l}\text { Identified the parts of Africa oppressed by } \\
\text { Europeans }\end{array}$ & $\begin{array}{l}\text { Identified countries engaging in state- } \\
\text { sponsored terror against their own people }\end{array}$ \\
\hline 10 & Nationalistic in nature & \begin{tabular}{l} 
Had a transnational outlook \\
\hline
\end{tabular}
\end{tabular}

citizens of states to express their patriotism for their countries by only engaging in those acts that edify and contribute to nation-building, which requires the rule of law. With good governance, it would be easier for African states to achieve the unity they desire in promoting equity. Bearing this in mind will give them the opportunity to accommodate people from all walks of life, irrespective of ethnic groups or nationality, for the actualization of Pan-African objectives.

The foregoing has a role to play in addressing the leadership question, which can only become a thing of the past when the leadership class begin to partner with the concerned Africans who have identified the instrumentality of the AAPC as a platform for the revolutionary initiative of the African solution to the current problems affecting the continent's increasing population.

Achieving this would boost the image of Africa and reduce the rate at which the majority of young people are desperate to leave the continent in 
droves for greener pastures in Europe, Asia, and the Americas. It has the capacity to improve mutually beneficial diplomatic relations between most African states and their counterparts in the core countries of the developed world. The success of the new Pan-Africanism will give Africans their desired voice despite their nationalist differences. Patriotic leaders who wish their people well would promote the effectiveness of the African peer review mechanism by welcoming other stakeholders in supporting them to manage internal problems and cannot allow their people to go through periods of avoidable humanitarian crisis occasioned by their self-centered policies.

One of the notable nationalist limitations has to do with the perception that achieving the unity of all African countries is almost impossible, just like the way it was earlier perceived that Kwame Nkrumah was desperately involved in the Pan-African endeavor in order to be the president in charge of Africa. This mentality of one state or individual trying to dominate others does not promote the needed unity of states despite the efforts of the advocates of Pan-Africanism. Similarly, Pan-Africanism, as it is today, has the limitation of convincing the states that have become the targets of some developed countries to understand the consequences of encouraging them to explore investment opportunities for access to emerging economies and markets in Africa. Moreover, the divisions occasioned by religious and ethnic affiliations are among other threats to Pan-Africanism ${ }^{58}$ that continue to hinder the creation of much-desired unity in the continent, which hosts a number of different religious movements.

From the foregoing, unity remains a major requirement in addressing internal and external problems. Ending white superiority for the interests of black people not only demands that the developed world prioritize equality for all but also that Africans begin to look inward and address their problems internally through socio-economic and strategic self-sufficiency rather than searching for development partners in the developed world. This cannot come overnight or by daydreaming by the leadership class, most of whom sometimes indulge in money laundering which remains a major source of capital flight. This negates the ideals of Pan-African progress.

The new Pan-Africanist initiative is an achievement that will sustain African unity through continuous collaboration and strengthening the African Union's Peace and Security Council in initiating peacemaking and peacebuilding activities for the continent's peace culture. African leaders cannot overcome the currency and trade wars fought by the developed countries in Europe and Asia while they are still receiving aid from developed countries. Therefore, advocacy for self-

58 Falola and Agbo, “The Prospects and Challenges of Pan-Africanism," 11. 
reliance would boost Africa's position in the current world order, reduce indebtedness, and enable states to address the resource governance crisis.

By implication, the new transnational Pan-Africanism cannot be achieved without the active involvement of scholars and institutions in Africa because they have a role to play in sustaining this desired consciousness in the areas of research and training. A change of perceptions is needed to avoid the probability of some people in Africa perceiving the initiative that has become synonymous with Ghana as a platform of politics for personal gain or benefit for only the advocates of the new transnational Pan-Africanism.

Some of its advocates and contributors cannot be said to be members of any known African country within the context of statehood or based on indigeneship. However, they have been able to identify with the continent in view of the need to create a platform for all to address prevailing continental problems and contribute to the development of Africa.

The new transnational Pan-Africanism as a construct means that different groups in Africa have to come together for specific goals despite their origins and political differences, thereby overcoming the limitations of group-based nationalism at a state level for wider transnational cooperation aimed at fulfilling the interests of black people. It is, however, not a platform for self-determination groups who may wish to use it as an opportunity to push for actualizing their political objectives. This transnational initiative recognizes existing states within the continent rather than the threat of de facto statehood in Africa. As part of the struggle to ensure that blacks overcome nationalist limitations, state-centric nationalism is not to be given the opportunity to overshadow the larger Pan-African need for cooperation and integration that would promote socio-economic justice and equity in the interest of all groups.

The fact that the new Pan-Africanism requires the effort of African leaders is a limitation, considering the differences of perceptions and how such a collaborative endeavor would be realized. Since it has been stated by Johnson and Njoku in their work "Towards a Wholesome Africa" that the leadership question is the greatest problem besetting the African continent, transnational Pan-Africanism is an opportunity for intellectuals and the elite to speak against the sit-tight leadership problem which creates the perception of the continent that harbors a "dictators' club," thereby reflecting the presence of numerous authoritarian heads of state who failed to relinquish power in their individual countries. ${ }^{59}$ The goal of this Pan-African initiative is to encourage change for the better for good governance as

59 Paul Reynolds, “African Union Replaces Dictators' Club,” BBC News, July 8, 2002, http:// news.bbc.co.uk/2/hi/africa/2115736.stm. 
part of the efforts to reposition Africa for Africans. This would have an appreciable impact on electoral processes and governance, thereby making it difficult for people to manipulate the electoral system to their own advantage, especially by delaying the release of election results, threatening political opponents perceived as stumbling blocks to their success, or rejecting results when defeated. These scenarios were recorded some years ago in the Côte d'Ivoire between Laurent Gbagbo and Alassane Ouattara (the then-leader was captured by soldiers loyal to Ouattara in April 2011), in Zimbabwe between the late Robert Mugabe and Morgan Tsvangirai, as well as in Kenya, Uganda, Equatorial Guinea, etc. With the new transnational Pan-Africanism, the liberation of Africa will be complete when internal oppression by the political elite in various states becomes a thing of the past.

Refocusing the political reality of Africa therefore demands consistent bridging of the institutional gaps in the areas of publication, intellectual exchanges, and elite scholars' collaborations for the development of Africa.

Beyond nationalist limitations, in the context of constructivist theory, transnational Pan-Africanism has several lessons for those engaged in contemporary Pan-Africanism to learn from the founding fathers of Africa who ignored their differences to champion the unity of African peoples. A notable characteristic of the new transnational Pan-Africanism is in its internal motivation rather than previous intervention efforts that were sometimes externally motivated by those in the diaspora. The new transnational Pan-Africanism should serve as leverage in African politics for the desired integration to be sustained by influencing the pattern of leadership, thereby making it more people-centered/participatory.

The coming together of scholars, practitioners, and leaders on the continent in the name of transnational Pan-Africanism will leverage the pattern of leadership among states. As far as the political reality of Africa is concerned, the new transnational Pan-Africanism is instrumental to the much-desired political transformation on the continent where leadership has become part of the continent's many challenges. This is so because getting it right as a people must begin with good governance. The manner in which some African leaders prioritize tenure elongation to the detriment of the populace is something that demands the attention of PanAfricanists. Tenure elongation has become a continental problem that undermines good governance, which has led to conflicts in various parts of Africa.

Such actions of leaders, if left unchecked, would make it difficult for African states to be united in addressing their internal security challenges, most of which are traceable to the politics of exclusion, greed/grievance, lopsided clamor for presidencies, and resource curse problems. Most African countries are bedeviled by agitations by political leaders to extend their tenure in office by amending the constitution to achieve their goals. What the average present-day African leader wants is the power to establish himself as a dynasty and imperial leader. This is 
inimical to good governance and transparent democracy. According to John Forje, the origins of indigenous African governments are traced back to Sudan (1956), Ghana (1957), Nigeria (1960), and many other countries that gained their independence in the 1960s. ${ }^{60}$ The continent is still far from being liberated from the leadership crises plaguing it, and the only way out is for the people to be united using the platform of transnational Pan-Africanism to leverage the governance processes, thereby making it complex for the ruling powers to become oppressive in office.

The leadership problem in Africa can no longer be allowed to continue without intervention by the people. Unless Africans form a political and economic union to tackle the intractable problems, the revolutions in the north of the continent, religious and ethnic strife, and civil wars in other parts of Africa are inevitable. Kwame Nkrumah already gave this warning in the past, but unfortunately, most leaders do not seem bothered about the consequences of their actions. Instead of political division, unity is the only way Africans can address their problems through effective leadership and all-inclusive and transparent governance.

\section{Conclusion and Recommendations}

This contribution has examined the new transnational Pan-Africanism and its nationalist limitations, which are not far from the political reality in Africa. It emphasized how the new transnational Pan-Africanism has sustained the efforts of the people of African descent through the platform of AAPC, which was first held in 1958 and later followed up in 2018. Takeaway lessons from those meetings are numerous. It is apparent that the destinies of African states remain in their hands and that realizing the dreams of the continent must attract African solutions to various challenges. The All-African Peoples' Conference is a contemporary initiative that remains instrumental to the renaissance of African solidarity and the sustainability of African consciousness. The initiative is not only people-oriented but collaborative in nature, requiring more understanding, information, conviction, determination, and cooperation from blacks within and outside Africa.

Despite the nationalist limitations, the new transnational Pan-Africanism has not only revived the Pan-African dream but has also brought awareness of

60 John W. Forje, "Self Determination, Nationalism, Development and Pan-Africanism Stuck on the Runway: Are Intellectuals to be Blamed?" African Journal of International Affairs 6, no. 1-2 (2003): 66. 
it closer to many blacks who may not have understood the origins and essence of such an endeavor, specifically through the platform of the AAPC.

The new Pan-Africanism established by the AAPCs of 1958 and 2018 have shown the readiness of blacks in the diaspora and their counterparts within the continent of Africa to continue from where the pioneers of the initiatives stopped. In keeping the morale as lively as desired, the movement and the ideology of PanAfricanism emphasize the fact that only Africans, rather than Europeans, Asians, or Americans, are in a position to salvage the people of the continent politically, economically, and socially. It points to the truism that only the people can transform the situation on the continent. If Pan-Africanists in the past could make such remarkable achievements without much technological advancement at that time, contemporary Africans should be held accountable if they fail to galvanize themselves for African unity and development, especially in this 21st-century era of globalization and technological revolution. It is instructive that with social media, Africans can revive Pan-Africanism and create more platforms that would promote intergroup relations for the benefit of the people.

Also, Pan-Africanism is one of the features of intergroup relations in Africa that portrays how Africans and those in the diaspora can discuss and plan for the future of the continent and redeem the battered image of the black race.

The difference between the 1958 and 2018 Pan-African conferences is that the former involved more political thinkers, members of civil society, and those from the grassroots with a focus on issues of decolonization and emancipation, while the latter focused on the need for self-reliance to salvage Africa from the neo-colonial crisis. Given that solidarity is the making of every socio-political movement, like the old Pan-African movement, the new Pan-Africanism remains a remarkable source of social, political, and economic transformations of the African continent. It served as a foundation of post-colonial Africa, creating a platform for peaceful collaboration and unity to achieve a common goal. Pan-Africanism emphasizes the unity of purpose amongst the people of 21st-century Africa, who have realized the urgency and advantages of taking their destinies into their own hands.

The strategic nature of the Pan-African endeavor shows that the post-colonial integration of African peoples is still achievable only if they cooperate beyond what their leaders have been doing through the platform of the African Union. Contemporary Pan-Africanism is a post-colonial endeavor that shifts from decolonization and emancipation to the self-rediscovery of African leaders and the re-evaluation of African culture to the rethinking of the conflict-oriented leadership styles of leaders whose high priority for the self encourages the politics of exclusion.

The study has also shown that the new Pan-Africanism has brought an African renaissance in the form of the reawakening of black consciousness from 
Europe and the Americas to Africa, where much-desired transformation has been urgently needed since the neo-colonial era that created a platform for the recolonization of the continent.

This contribution suggests that until African leaders unite, adopt transnational Pan-Africanism, and look inward, it would be difficult to overcome various political, economic, and technological challenges that are linked to neo-colonialism. Options for the eradication of these problems are situated within the framework of new Pan-African nationalism in addressing the leadership question in Africa. Scholars have a role to play in sustaining this desired consciousness in the areas of research and training. The political class and Pan-African scholars have a lot to benefit from the scientific work related to the Kwame Nkrumah Chair in African Studies at the University of Ghana, and this will serve as a knowledge base for countering neo-colonialism as far as overcoming the nationalist limitations of the new transnational Pan-Africanism are concerned.

\section{Works Cited}

Adejumobi, Said. "Popular Participation and Africa's Development Agenda: Projecting a Citizen-Based United States of Africa." Politikon: South African Journal of Political Studies 36, no. 3 (2009): 403-422.

Akpomuvie, Orhioghene Benedict. "Pan-Africanism and the Challenges of Development in the 21st Century.” Africana 4, no. 2 (2010): 191-212.

Alder, Emanuel. "Seizing the Middle Ground: Constructivism in World Politics." European Journal of International Relations 3, no. 3 (1997): 319-363.

Alexander, Franklin. "A critique of neo-Pan-Africanism." The Black Scholar: Journal of Black Studies and Research 4, no. 10 (1973): 9-15.

Aniche, Ernest T. "From Pan-Africanism to African Regionalism: A Chronicle." African Studies 79, no. 1 (2020): 70-87.

Asante, Samuel Kwadwo B. Regionalism and Africa's Development: Expectations, Development, and Challenges. London: Macmillan, 1997.

Aterianus-Owanga, Alice. "A Pan-African Space in Cape Town? The Chimurenga Archive of PanAfrican Festivals." Journal of African Cultural Studies (2019): 1-19.

Barth, Fredrik. "Introduction." In Ethnic Groups and Boundaries: The Social Organization of Culture and Difference, edited by Fredrik Barth. Boston: Little Brown and Company, 1969.

Boogaard, Vanessa Van den. "Modern post-colonial approaches to citizenship: Kwame Nkrumah's political thought on Pan-Africanism." Citizenship Studies 21, no. 1 (2017): 44-67.

Bunting, Ikaweba. "Towards a Pan African Political Culture: Critical Pedagogy, Reparative Justice and the End of Global White Supremacy." Contemporary Journal of African Studies 6, no. 1 (2019): 138-157.

Chouin, Gerard and Olanrewaju O. Lasisi. "Crisis and transformation in the Bight of Benin at the Dawn of the Atlantic Trade." In Power, Political Economy and Historical Landscapes of 
the Modern World: Interdisciplinary Perspectives, edited by Christopher R. DeCorse, 285-306. Albany, NY: State University of New York Press, 2019.

Davidson, Basil. The Back Man's Burden: Africa and the Course of the Nation-State. Ibadan: Spectrum Books Ltd, 1992.

Esedebe, Olisanwuche Peter. "The Emergence of Pan African Ideas." In Themes in African Social and Political Thought, edited by Onigu Otite. Enugu: Fourth Dimension Publishing, 1978.

Falola, Toyin and Chukwuemeka Agbo. "The Prospects and Challenges of Pan-Africanism.” Oxford Research Encyclopedia: Politics (2019): 1-21.

Forje, John W. "Self Determination, Nationalism, Development and Pan-Africanism Stuck on the Runway: Are Intellectuals to be Blamed?" African Journal of International Affairs 6, no. 1-2 (2003): 54-86.

Fuller, Harcourt. Building the Ghanaian Nation State: Kwame Nkrumah's Symbolic Nationalism. USA: Palgrave Macmillan, 2014.

Ifidon, Ehimika Adebayo. "Did Pan-Africanism beget Nationalism? Race and Territory in the Discourse on Pan-Africanism." Lagos Historical Review 8 (2008): 113-131.

Kai, Nubia. "Footprints of Pan-Africanism." Journal of African Literature Association 12, no. 3 (2018): 361-363.

Kasanda, Albert. “Exploring Pan-Africanism's Theories: From Race-based Solidarity to Political unity and beyond." Journal of African Cultural Studies 28, no. 2 (2016): 179-195.

Kendhammer, Brandon. "DuBois the Pan-Africanist and the Development of African Nationalism." Ethnic and Racial Studies 30, no. 1 (2007): 51-71.

Legum, Colin. Pan-Africanism: A Short Political Guide. New York: Frederick A. Praeger, 1965.

Malisa, Mark and Phillippa Nhengeze. "Pan-Africanism: A Quest for Liberation and the Pursuit of a United Africa." Genealogy 2, no. 28 (2018): 1-15.

McKenna, Lindsay. Commando. Don Mills, Ont.: Harlequin Enterprises, 2013.

Middleton, William J. "Pan-Africanism: A historical analysis and critique.” The Black Scholar: Journal of Black Studies and Research 1, no. 3-4 (1970): 58-64.

Momoh, Abubakar. "Does Pan-Africanism Have a Future in Africa? In Search of the Ideational Basis of Afro-Pessimism." African Journal of Political Science 8, no. 1 (2003): 31-57.

Mutiso, Gideon Y. M. and S. W. Rohio, eds. Readings in African Political Thought. London: Heinemann Educational Books, 1974.

Ndlovu-Gatsheni, Sabelo J. "Pan-Africanism and the international system." In Handbook of Africa's International Relations, edited by Tim Murithi, 21-29. London: Routledge, 2013.

Odamtten, Harry N. K. Edward W. Blyden's Intellectual Transformations: Afropublicanism, PanAfricanism, Islam, and the Indigenous West African Church. Michigan: Michigan State University Press, 2019.

Ola, Opeyemi. “Pan-Africanism: An Ideology of Development.” Présence Africaine 4, no. 112 (1979): 66-95.

Olanrewaju, Jide. n.d. "The Story of Nigeria. Naij, A History of Nigeria."

Otunla, Timothy A. "Pan-Africanism with the African Union: Policy Options for Nigeria." In New Horizons for Nigeria in World Affairs, edited by Joy U. Ogwu, 313-334. Lagos: The Nigerian Institute of International Affairs, 2005.

Potekhin, Ivan. "Pan-Africanism and the Struggle of the Two Ideologies." South Africa History Online (October 1964): 36-48.

Reynolds, Paul. “African Union Replaces Dictators' Club.” BBC News, July 8, 2002. http:// news.bbc.co.uk/2/hi/africa/2115736.stm. 
Rodney, Walter. How Europe Underdeveloped Africa. London: Bogle-L'Ouverture Publications, 1972.

Schramm, Katharina. "Pan-Africanism as a Resource: The W. E. B. DuBois Memorial Centre for Pan-African Culture in Ghana." African Identities 2, no. 2 (2004): 151-171.

Smith, Anthony D. S. Nationalism in the Twentieth Century. Oxford: Martin Robertson, 1979.

Tsomondo, Micah S. "From Pan-Africanism to Socialism: The Modernization of an African Liberation Ideology." Issue: A Journal of Opinion 5, no. 4 (1975): 39-46.

Uzoigwe, Godfrey N. "A Matter of Identity: Africa and Its Diaspora in America Since 1900, Continuity and Change." African and Asian Studies 7 (2008): 259-288.

Valentim, Joaquim Pires. "Sherif's Theoretical Concepts and Intergroup Relations Studies: Notes for a Positive Interdependence." Psychologica 52, no. II (2010): 585-598.

Wimmer, Andreas. "The Making and Unmaking of Ethnic Boundaries: A Multilevel Process Theory." American Journal of Sociology 113, no. 4 (2008): 970-1022.

Yimenu, Shibabaw. "Pan-Africanism and African Economic Development." The Black Scholar: Journal of Black Studies and Research 6, no. 8 (1975): 32-40.

Young, Kurt B. "Towards a Holistic Review of Pan-Africanism: Linking the Idea and the Movement." Nationalism and Ethnic Politics 16, no. 2 (2010): 141-163. 
